\title{
Organic Versus Mineral Fertilization Regimes in Relation to Potato Brown Rot Suppression and Crop Production
}

\section{Messiha, N.A.S. and Elhalag, K.M.A.}

Bacterial Dis. Res. Dept., Plant Pathology Research Institute, Agricultural Research Center, Giza, Egypt.

The effect of different fertilization regimes on potato bacterial wilt, caused by Ralstonia solanacearum was evaluated in four different naturally infested districts in two successive years 2013 and 2014. The effect of different fertilization components on disease suppression and potato yield varied from place to another according to different edaphic factors. Area 1 (Manyl-Arus) with clay soil was characterized by high $\mathrm{C} / \mathrm{N}$ ratio (13) and low electric conductivity EC $(0.06 \mathrm{ds} / \mathrm{m})$. Area 2 (Ganoub El-Tahrir) with sandy soil was characterized by low $\mathrm{C} / \mathrm{N}$ ratio (5) and low organic matter $(\mathrm{OM})$. Area 3 (Talia area) with clay soil was characterized by high EC $(0.37 \mathrm{ds} / \mathrm{m})$, high $\mathrm{OM}(2.2 \%)$ and high total organic carbon (TOC) $(0.99 \%)$. While, area 4 (Wardan area) with sandy soil was characterized by high $\mathrm{pH}(8.8)$ and low TOC (0.04\%). NPK showed a remarkable disease suppression that was most clear under high alkalinity at area 4 . NPK improved potato yield with a reasonable increase in amino acids in root exudates. Replacing potassium with magnesium (NPMg) suppressed the disease at different areas and decreased Peroxidase (PO), Polyphenol oxidase (PPO) with a remarkable increase in Tyrosin ammonia lyase (TAL) activities. Apparent vegetative growth and/or potato yield were recognized in this treatment. Disease suppression by replacing potassium with calcium (NPCa) was correlated with decrease in PO, PPO and an increase in Catalase (CAT) activities. Composted chicken manure suppressed the disease only in soil of area 1 and plant rhizosphere of area 4 . The disease decline in area 1 was correlated to the decreased activity of PO \& PPO and increased ones in TAL (similar to $\mathrm{NPMg}$ treatment). High ammonium and low content of variety of amino acids were shown in potato root exudates with dominance of glycine, proline, serine and threonine. Plant-animal compost complex suppressed the disease at area 1 and area 4 but not at area 3. The complex treatment showed an increase in both amino acids and $\mathrm{NH}_{4}^{+}$as compared to untreated control. High ratio of aspartic (acidic) and arginine (basic) was recorded. Plant-animal compost complex showed a remarkable decrease in soil organic matter which was associated with a narrow $\mathrm{C} / \mathrm{N}$ ratio and limited $\mathrm{N}$ and $\mathrm{K}$ plant uptake at Talia area.

Keywords: Ralstonia solanacearum Enzyme activity; root exudates; Plant-animal compost; OM; $\mathrm{C} / \mathrm{N}$ ratio; disease suppression 
Potato brown rot (bacterial wilt), caused by $R$. solanacearum race 3 biovar 2 (Phylovar II, sequevar 1), is ranked as the second most important pandemic bacterial plant pathogens. Up to $90 \%$ crop loss due to the disease was recorded in different areas worldwide (Elphinstone, 2005). The pathogen is able to survive in soil for long period, spread through irrigation and drainage water and survive in alternative weeds hosts (Wang and Lin, 2005). Deficiencies of certain elements often resulted in an increase susceptibility to diseases. Meanwhile, high calcium is often positively related to increased resistance against bacterial diseases as it is considered as a plant defense signaling key (Lecourieux et al., 2006). Also, Organic amendments often cause faster decline of $R$. solanacearum in soil along with disease suppression as postulated by Messiha et al. (2007), Messiha et a., (2009) and Hagag et al. (2015).

The amino acids content in root exudates reflects plant growth, and affects root colonizing microorganisms as well as pathogen fitness (Moe, 2013). Root exudates have a signaling role in the pathogenesis process when plant is under threaten by different pathogens (Ryan and Delhaize, 2001). High amino acids content attracts non-pathogenic microorganisms such as some fluorescent pseudomonads (Katsuwon and Anderson, 1990), and playing an important role in survival of specific biocontrol agents in plant rhizosphere (Elhalag et al., 2015).

Enzymes such as phenylalanine ammonia-lyase (PAL), peroxidase (PO), polyphenoloxidase (PPO), catalase (CAT) play important roles in disease progress (Taranto et al., 2017 and Zhao et al., 2008). Phenyl alanine ammonia lyase (PAL) catalyzes the biosynthesis of phenolics, phytoalexin and lignin (Boubakri et al., 2013). Pathogenesis is always associated with generation of reactive oxygen species (ROS). Several enzymes are involved in removal of ROS and hence enhance plant defense such as PO and CAT enzymes (Sharma et al., 2012)

The objective of this work is the study of certain regimes of fertilizers application and their influence on potato as related to brown rot disease progress as well as crop production.

\section{Materials and Methods}

The effect of different organo-chemical fertilization regimes on potato brown rot was evaluated in four naturally infested fields during two successive years 2013 and 2014, in different soil textures. The experimental locations were selected in area 1(clay soil) at Manyl Arus, Minufiya; area 2 (sandy soil) at Ganoub El-Tahrir, Behera; area 3 (clay soil) at Talia- Minufiya and area 4 (sandy soil) at Wardan, Giza governorate.

Susceptible potato variety, "Lady Rosetta", was used for planting during the first year in area 1 and $2\left(31^{\circ} 1^{\prime} 45.94 " \mathrm{E} ; 30^{\circ} 13^{\prime} 7.17^{\prime \prime} \mathrm{N}\right)$ and $\left(30^{\circ} 43^{\prime} 24.60^{\prime \prime} \mathrm{E}\right.$, $30^{\circ} 29^{\prime} 22.80 " \mathrm{~N}$ ), respectively. Early maturing potato variety, Spunta, was used for planting in clay soil area 3 and $4\left(30^{\circ} 58^{\prime} 28.69^{\prime \prime} \mathrm{E},=30^{\circ} 15^{\prime} 49.54^{\prime \prime} \mathrm{N}\right)$ and 
$\left.30^{\circ} 56^{\prime} 8.93 " \mathrm{E}, 30^{\circ} 20^{\prime} 29.31^{\prime \prime} \mathrm{N}\right)$ during the second year. Each treatment was replicated by three plots, each plot was $10 \times 10 \mathrm{~m}^{2}$ with $1 \mathrm{~m}$ interspace between different plots. The factorial experiment was designed and statistically analysed as completely randomized trials. The following treatments were made.

1- Control un-treated;

2- NPK (N (170kg/ha) + P (52kg/ha) + K (206kg/ha));

3- NPMg (K was replaced by $\mathrm{Mg}(30 \mathrm{~kg} / \mathrm{ha}))$;

4- NPCa, K was replaced by $\mathrm{Ca}(30 \mathrm{~kg} / \mathrm{ha}))$;

5- Composted chicken manure $2.76,0.89$ and $2.74 \%$, respectively NPK) for the first year and (2.3, 1.6 and $2.87 \%$ respectively for NPK) for the second year;

6- Plant animal compost (1:1 wt.) (NPK 0.44, 0.12 and 1.36\%) for the first year and $(0.86 \%, 0.39 \%$ and $0.57 \%$ NPK) for the second year.

The amount of applied nitrogen was standardized to be $170 \mathrm{Kg} \mathrm{N} / \mathrm{ha}$, from different organic and inorganic sources. The applied mineral nitrogen was divided into three equal doses according to growth stages as concerning vegetative growth, tuberization and tuber bulking stages. Potassium sulphate was applied at equal doses at the second and third potato growth phases only. Organic fertilizers were applied during agricultural practices prior planting.

\section{Soil and plant analysis}

Soil samples were collected from untreated soils at Zero time before planting and after 90 days from planting for other treatments for analysis. Analysis was done at the "National Research Center", Dokki, Egypt. Analysis included determination of $\mathrm{pH}$, electric conductivity (EC), organic matter $(\mathrm{OM})$, NPK contents and $\mathrm{C} / \mathrm{N}$ ratio following the protocols described by Farag et al., (2017).

Effect of fertilization regimes on bacterial wilt incidence:

Wilt incidence and densities of the pathogen in soil, rhizosphere soil and crown area were the basic parameters for evaluation the effect of fertilization as previously evaluated. Plants were surveyed for wilt symptoms. Five soil and plant samples from each field plot were pooled together for each treatment and each sample was extracted in phosphate buffer (PB 0.05M) and was spread on two sets of SMSA (Selective Medium South Africa) plates. The population count of Ralstonia solanacearum (Colony forming units (CFUs) per gram soil and tissues) were determined according to Anonymous (1998). Typical colonies were serologically confirmed by Immunofluorescence Antibody Staining (IFAS) and/or Real-Time Fluorogenic PCR (TaqMan) assay according to Weller et al., (2000) followed by pathogenicity test (Janse, 1988). Finally, wilt incidence at the end of each year was determined according to Thanh et al., (2009).

Effect of fertilizers on enzymes activity:

Three plant samples from each plot were collected 75 days after planting, transferred lab in an iceboxes, washed (in tap water followed by sterile water), and 
directly stored at $-30^{\circ} \mathrm{C}$. Leaves representing each treatment were pooled together for enzyme(s) extraction. Enzyme determinations were made at the Central Lab of Biotechnology, Plant Pathology Research Institute (PPRI, ARC). The levels of peroxidase (PO) (EC 1.11.1.7), and polyphenol oxidase (PPO), (EC 1.10.3.1) were determined according to Benjamin and Montgomery (1973), phenylalanine ammonia lyase (PAL; E.C.4.3.1.24) and tyrosine ammonia lyase (TAL; E.C.4.3.1.23) according to Berner et al. (2006) were determined using Beckman Coulter DU 800 spectrophotometer. The increase in absorbance was recorded each 30 seconds (10 readings). The rate of catalyzed enzyme reaction was proportional with the amount of the enzyme in the leaf extract. The catalase CAT (EC 1.11.1.6) was determined according to Aebi (1984). The relation between enzymes activities and disease incidence was discussed.

\section{Analysis of root exudates}

Root exudates of potato plants grown under different fertilization regimes were separately collected at plant age of 75 days according to Graham et al., (1981), and Thomson et al., (1986). In brief, root samples from each pot treatment were removed from their soil containers and was carefully washed, immediately placed in a beaker with the roots completely covered with $0.5 \mathrm{mM} \mathrm{CaCl}_{2}$ solution containing $0.05 \mathrm{~g} / \mathrm{l}$ rifampicin and $0.025 \mathrm{~g} / \mathrm{l}$ tetracycline to eliminate bacterial populations and incubated for $3 \mathrm{~h}$ under continuous low light at room temperature then the roots were washed by distilled sterile water twice to remove the antibiotics residues. The roots were reimmersed in $0.5 \mathrm{mM} \mathrm{CaCl} 2$ solution for 2 hours (for root exudates equilibration), then roots were transferred to fresh flasks containing fresh $0.5 \mathrm{mM} \mathrm{CaCl}_{2}$ solution for 6 hours, root exudates were collected and the roots were transferred to other fresh solution for further 6 hours. The collected root exudates for each sample were pooled together and were filtrated by $0.20 \mu \mathrm{m}$ disposable bacterial filter for amino acid analysis. Amino acid analyses of the extracted root exudates were carried out at the National Research Centre (NRC) using an amino acid analyzer (Biotronic $L C$ 3000; Eppendorf, Hamburg, Germany.

\section{Effect of different fertilizers on plant growth and crop production:}

The criteria used for estimation of growth parameters were, plant height, ratio of leaves weight to total shoots, fresh and dry weights as well as crop yield scale which was determined per plot and was extrapolated to feddan (approx. $0.5 \mathrm{ha}$ ).

\section{Statistical Analysis:}

Mann-Whitney U, Asymp. Sig. (2-tailed) was employed to compare parameters of disease incidence, plant morphology and crop production for different treatments as compared to untreated controls using SPSS 17.

Pearson correlation, 2 tailed, SPSS 17 was conducted to correlate the disease incidence and crop production and to correlate the disease incidence with the amino acids content in potato root exudates (Messiha et al., 2009).

Egypt. J. Phytopathol., Vol. 47, No. 1 (2019) 


\section{Res u l t s}

\section{1- Soil analysis}

Area 1 (Manyl Arus) is characterized with high $\mathrm{C} / \mathrm{N}$ ratio (13) and low EC (0.06 $\mathrm{ds} / \mathrm{m}$ ). Area 2 (Ganoub El-Tahrir) characterized with very low $\mathrm{C} / \mathrm{N}$ ratio (5) which was correlated to low OM\% (0.3). Area 3 (Talia) showed high EC (0.37 ds/m), high $\mathrm{OM}$ and organic carbon ratios (2.2 and 1\%) respectively. Area 4 (Wardan) was characterized with high alkalinity $(\mathrm{pH} 8.8)$ and lowest organic carbon ratio $(0.04 \%)$. Table (1) summarizes the chemical characteristics of different untreated soils prior experimentation.

Table (1): Chemical characteristics for soils from different locations prior starting the experiment

\begin{tabular}{llccccc}
\hline & $\mathrm{pH}$ & $\begin{array}{c}\mathrm{EC} \\
\mathrm{ds} / \mathrm{m}\end{array}$ & $\begin{array}{c}\mathrm{C} / \mathrm{N} \\
\text { ratio }\end{array}$ & $\begin{array}{c}\text { Organic } \\
\text { matter } \\
(\mathrm{OM}) \%\end{array}$ & $\begin{array}{c}\text { Total } \\
\text { organic } \\
\text { carbon } \\
\text { (TOC) \% }\end{array}$ \\
\hline \multirow{2}{*}{ Year 1 } & Manyl-Arus & 8.2 & 0.06 & 13 & 1.5 & 0.89 \\
& Ganoub El-Tahrir & 8.3 & 0.26 & 5 & 0.3 & 0.20 \\
\hline \multirow{2}{*}{ Year 2 } & Talia & 8.2 & 0.37 & 11 & 2.2 & 0.99 \\
& Wardan & 8.8 & 0.10 & 10 & 1.3 & 0.04 \\
\hline
\end{tabular}

2- Effect of different regime on soil and plant chemistry

Soil and plant characteristics of control treatment are shown in Table (2). Soil analysis for area 3 (Talia) showed $\mathrm{C} / \mathrm{N}$ ratio of 11 along with alkaline $\mathrm{pH}$ (8.18), EC $(0.37 \mathrm{dS} / \mathrm{m})$ and organic matter $(\mathrm{OM})(2.18 \%)$. N, P and $\mathrm{K}$ values in soil were 112 , 1.43 and $41.6 \mathrm{mg} / 100 \mathrm{~g}$, respectively. The NPK values at area 3 were higher in general as compared with area 4 (Wardan). The starting NPK in plant were 4.25, 0.096 and $3.23 \%$, respectively. At area 4 (Wardan) area the untreated soil showed $\mathrm{C} / \mathrm{N}$ ratio of 10 , alkaline $\mathrm{pH}(8.83)$, EC was $(0.1 \mathrm{dS} / \mathrm{m}), \mathrm{OM}(1.33 \%)$. N, P and $\mathrm{K}$ soil were $74,2.73$ and $8.86 \mathrm{mg} / 100 \mathrm{~g}$ respectively. The NPK values in plant were $3.07,0.083$ and $3.98 \%$, respectively (Table 2 ).

NPK treatment at area 3 (Talia) caused 13\% decrease in organic matter which was associated with a decrease in $\mathrm{C} / \mathrm{N}$ ratio. Increase in soil NPK values $(16,64$, and $69 \%$ respectively) and in plant N, K (5 and 25\%, respectively) were recorded. NPK treatment at area 4 (Wardan) caused a considerable increase in soil NPK (4, 48 and $29 \%$ ), respectively. The corresponding figure in plant treatment was $7 \%$ increase in $\mathrm{N}$ and $29 \%$ decrease in K, compared to the control. Such slight increase in $\mathrm{N}$ and decrease in $\mathrm{K}$ content may be attributed to soil alkalinity $(\mathrm{pH} \mathrm{8.83)} \mathrm{that} \mathrm{affecting}$ nutrient uptake, or plant selectivity along with possible physical changes in edaphic factors. 
Table (2): Effect of application of different fertilization regimes on NPK content of potato tissues and soil at 90 days of potato cultivation under field conditions

\begin{tabular}{|c|c|c|c|c|c|c|c|c|}
\hline \multirow{3}{*}{ Area } & \multirow{3}{*}{ Treatments } & \multicolumn{7}{|c|}{ Soil analysis } \\
\hline & & \multirow{2}{*}{$\mathrm{pH}^{2}$} & \multirow{2}{*}{$\begin{array}{c}\mathrm{EC}^{3} \\
(\mathrm{dS} / \mathrm{m})\end{array}$} & \multirow{2}{*}{$\begin{array}{c}\mathrm{OM}^{4} \\
\%\end{array}$} & \multirow{2}{*}{$\begin{array}{l}\mathrm{C}: \mathrm{N}^{5} \\
\text { ratio }\end{array}$} & $\mathrm{N}^{6}$ & $\mathrm{P}^{7}$ & $\mathrm{~K}$ \\
\hline & & & & & & \multicolumn{3}{|c|}{$\mathrm{mg} / 100 \mathrm{~g}$} \\
\hline \multirow{6}{*}{ Talia } & Untreated control & 8.18 & 0.37 & 2.18 & 11:01 & 112 & 1.43 & 41.6 \\
\hline & NPK & 8.01 & 0.55 & 1.90 & $9: 01$ & 130 & 2.34 & 70.2 \\
\hline & $\mathrm{NPMg}$ & 7.99 & 0.66 & 1.84 & $8: 01$ & 130 & 2.6 & 63.4 \\
\hline & $\mathrm{NPCa}$ & 8.12 & 0.46 & 2.24 & 10:01 & 131 & 2.86 & 56.0 \\
\hline & Composted chicken manure & 7.88 & 0.64 & 2.90 & 13:01 & 126 & 2.34 & 58.4 \\
\hline & Plant-animal compost & 8.15 & 0.48 & 1.22 & $6: 01$ & 130 & 3.27 & 56.4 \\
\hline \multirow{6}{*}{ Wardan } & Untreated control & 8.83 & 0.10 & 1.33 & $10: 01$ & 74 & 2.73 & 8.86 \\
\hline & NPK & 8.83 & 0.15 & 1.33 & 10:01 & 77 & 4.03 & 11.44 \\
\hline & $\mathrm{NPMg}$ & 8.81 & 0.09 & 1.42 & 11:01 & 74 & 2.6 & 7.7 \\
\hline & $\mathrm{NPCa}$ & 8.48 & 0.10 & 1.22 & 10:01 & 72 & 2.47 & 7.12 \\
\hline & Composted chicken manure & 8.84 & 0.10 & 1.43 & $12: 01$ & 72 & 3.12 & 10.1 \\
\hline & Plant-animal compost & 8.84 & 0.15 & 1.73 & 14:01 & 72 & 2.98 & 19.2 \\
\hline \multirow{3}{*}{ Area } & \multirow{3}{*}{ Treatments } & \multicolumn{3}{|c|}{ Plant analysis } & \multicolumn{4}{|c|}{$R$. solanacearum count } \\
\hline & & \multirow{2}{*}{$\mathrm{N} \%^{1}$} & \multirow{2}{*}{$\mathrm{P} \%$} & \multirow{2}{*}{$\mathrm{K} \%$} & \multicolumn{4}{|c|}{$\log 10(\mathrm{CFU}+1)$} \\
\hline & & & & & Rhizosp & $2,3,4,5,7$ & Cro & $\operatorname{area}^{1}$ \\
\hline \multirow{6}{*}{ Talia } & Untreated control & 4.25 & 0.096 & 3.23 & \multicolumn{2}{|c|}{$5.99 \pm 0.36$} & \multicolumn{2}{|c|}{$3.12 \pm 0.17$} \\
\hline & NPK & 4.45 & 0.096 & 4.05 & \multicolumn{2}{|c|}{$3.69 \pm 1.88$} & \multicolumn{2}{|c|}{$2.61 \pm 0.5$} \\
\hline & $\mathrm{NPMg}$ & 4.19 & 0.063 & 3.77 & \multicolumn{2}{|c|}{$1.93 \pm 1.93$} & \multicolumn{2}{|c|}{$0.64 \pm 0.64$} \\
\hline & $\mathrm{NPCa}$ & 4.00 & 0.044 & 3.93 & \multicolumn{2}{|c|}{$3.63 \pm 1.84$} & \multicolumn{2}{|c|}{$2.76 \pm 0.24$} \\
\hline & Composted chicken manure & 5.63 & 0.068 & 2.90 & \multicolumn{2}{|c|}{$1.87 \pm 1.87$} & \multicolumn{2}{|c|}{$2.66 \pm 0.18$} \\
\hline & Plant-animal compost & 4.38 & 0.083 & 3.52 & \multicolumn{2}{|c|}{$6.2 \pm 0.19$} & $1.9^{-}$ & 0.99 \\
\hline & Untreated control & 3.07 & 0.083 & 3.98 & 1.82 & & 2.3 & 1.42 \\
\hline & NPK & 3.30 & 0.081 & 2.83 & & & & \\
\hline $\mathbf{u}$ & $\mathrm{NPMg}$ & 3.25 & 0.078 & 1.92 & & & & \\
\hline wardan & $\mathrm{NPCa}$ & 3.66 & 0.096 & 2.35 & 1.82 & & 0.5 & 0.54 \\
\hline & Composted chicken manure & 3.36 & 0.096 & 4.39 & & & 0.75 & 0.75 \\
\hline & Plant-animal compost & 3.47 & 0.053 & 4.89 & 1.31 & & & \\
\hline
\end{tabular}

${ }^{1}$ Significant correlation $(+0.58, P=0.02)$

${ }^{2}$ Significant correlation $(-0.64, P=0.01)$, the relation was reversed for Talia $(+0.88, P=0.01)$

${ }^{3}$ Significant correlation $(+0.5, P=0.037)$, the relation was reversed for Talia $(-0.87, P=0.01)$

${ }^{4}$ Trend of significant correlation $(-0.57, P=0.1)$

${ }^{5}$ Significant correlation $(-0.5, P=0.05)$

${ }^{6}$ Significant correlation $(+0.69, P=0.007)$

${ }^{7}$ Significant correlation $(0.45, P=0.07)$

${ }^{8}$ General trend of significant correlation $(+0.63, P=0.1)$, the relation was reversed for Talia ( $0.57, P=0.1$ )

NPMg treatment at area 4 (Wardan) caused 6\%, increase in N, 52\% decrease in plant $\mathrm{K}$ and $13 \%$ decrease in soil $\mathrm{K}$ as compared to untreated control.

NPCa on the other hand, increased NP uptake in plant by 19 and $16 \%$, respectively only at area 4 (Wardan).

Egypt. J. Phytopathol., Vol. 47, No. 1 (2019) 
Replacing $\mathrm{K}$ with $\mathrm{Mg}$ in $\mathrm{NPMg}$ treatment at area 3 (Talia) caused a slight decrease in $\mathrm{pH}(8)$ and increase in $\mathrm{EC}(0.66 \mathrm{dS} / \mathrm{m})$. The decrease in $\mathrm{C} / \mathrm{N}$ ratio was associated with $16 \%$ decrease in soil OM. The decrease in OM content was associated with unexpected increase in plant K (16.7\%) and available soil K (52\%) as compared to the untreated control.

Composted chicken manure treatment at area 3 (Talia) increased the $\mathrm{C} / \mathrm{N}$ ratio in soil, being 13 which was associated with an increase in soil OM content, being $2.9 \%$ and increased $\mathrm{N}$ uptake (34\% increase as compared to untreated control). At area 4 (Wardan), the treatment increased NPK in plants and recorded an increase of 9, 16 and $10 \%$, respectively compared to the untreated control, with slight decrease in soil and a pronounced increase in soil phosphorous and potassium.

Plant-animal compost, however, caused a slight increase in $\mathrm{N}$ and $\mathrm{K}$ uptake by plant at area 3 (Talia) which was associated with a decrease in $\mathrm{C} / \mathrm{N}$ ratio (6) and a drastic decrease in $\mathrm{OM}$ into $1.22 \%$. For area 4 (Wardan), the increase in $\mathrm{N}$ and $\mathrm{K}$ uptake was recorded 13 and $23 \%$, respectively as compared to untreated control and soil by 23 and $117 \%$, respectively. With regard to organic matter, the treatment caused 30\% increase as compared with untreated control which was associated with an increase in $\mathrm{C} / \mathrm{N}$ ratio into 13 . (Table 2)

\section{3- Effect of organo-mineral fertilizers on bacterial wilt incidence:}

Different treatments were ineffective in decreasing disease incidence at area 2 (Ganoub El-Tahrir), where the $\mathrm{C} / \mathrm{N}$ ratio and $\mathrm{OM}$ were low.

NPK decreased the pathogen in soil $(71 \%, P=0.05)$ at area 1 (Manyl Arus) and to an undetectable level in the rhizosphere and plant tissues $(P=0.006)$ at Wardan area.

However, replaced potassium with magnesium in the latter, NPK treatment decreased the pathogen in the crown area only $(100 \%, P=0.08)$ at area 1 (ManylArus). At area 3 (Talia), NPMg decreased the count of the pathogen in plant tissues (79\% decrease) from $(3.11 \pm 0.17)$ to $(0.64 \pm 0.64),(P=0.007)$ (Fig 1). At area 4 (Wardan), NPMg decreased the count of the pathogen in the soil, rhizosphere and plant tissues upto undetectable level $(P=0.006)$.

NPCa significantly decreased the pathogen in soil $(100 \%, P=0.006)$, in crown area $(100 \%, P=0.08)$ at area 1 (Manyl-Arus), NPCa caused absence of wilt symptoms as compared to $0.33 \%$ for untreated control (data not shown). Only a trend of significant decrease in count of the pathogen in potato tissues $(0.54 \pm 0.54)$ reaching $76.5 \%$ was recorded for NPCa treatment (Fig 1). 

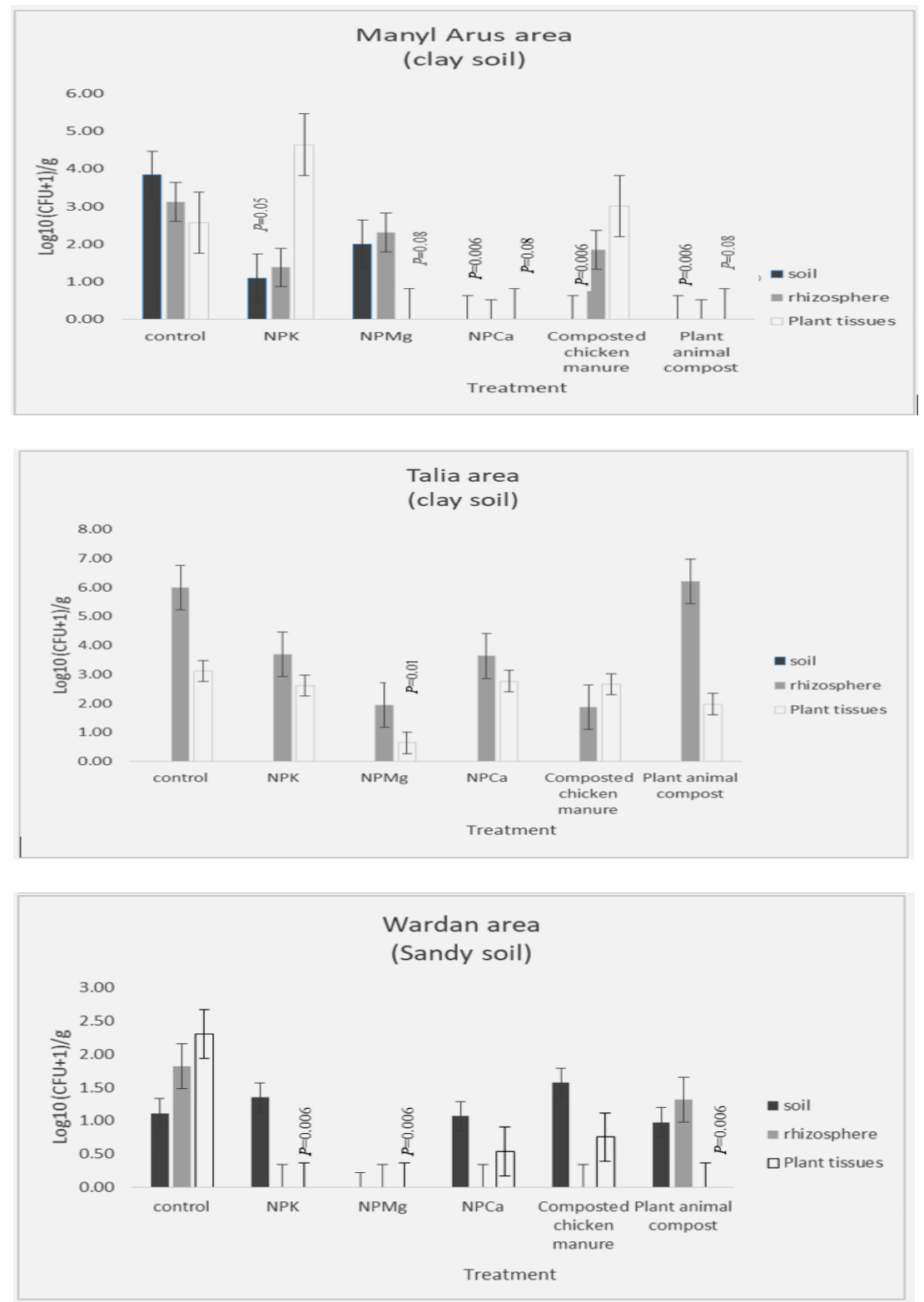

Fig (1): Disease incidence for different fertilization regimes at different locations.

Egypt. J. Phytopathol., Vol. 47, No. 1 (2019) 
Composted chicken manure decreased the pathogen in soil at a significant extent $(100 \%, P=0.006)$ at area 1 (Manyl-Arus) and was not effective at area 3 (Talia). At area 4 (Wardan), apparent decrease in pathogen count was detected in potato rhizosphere upto undetectable level, and $67 \%$ decrease in the count of the pathogen in plant tissues $(0.75 \pm 0.75)$.

Plant-animal compost decreased the pathogen density in soil to a significant extent $(100 \%, P=0.006)$, and crown area $(100 \%, P=0.08)$ at area 1 (Manyl-Arus) and was not effective in area 3 (Talia). At area 4 (Wardan), plant-animal compost decreased the pathogen density in the plant tissues to undetectable level $(P=0.006)$ (Fig 1).

\section{4- Effect of fertilizers on enzymes activity:}

A negative correlation between disease incidence, as expressed by counts of the pathogen in crown area, and PO \& PAL activity $(-0.5, P=0.05) \&(-0.52, P=0.04)$ was recorded.

NPK caused an increase in CAT and a decrease in PPO at area 4 (Wardan) where the disease was suppressed, the reverse was observed at area 3 (Talia) where the disease was un- affected. NPMg decreased PO and PPO activities and increased TAL activity which was associated with disease suppression. NPCa caused an increase in CAT and a decrease in the activity of most enzymes (PO, PPO, PAL and TAL) when the disease was suppressed. Composted manure increased CAT activities were only when the disease was suppressed in plant tissues at area 4 (Wardan) while the CAT activities decreased when the disease was not suppressed at area 1 (Manyl-Arus) and area 3 (Talia). Plant-animal compost caused general decrease in most investigated enzymes except PAL activity (Table 3).

\section{5- Potato root exudates under different fertilization regimes:}

Root exudates of unfertilized control treatments were poor enough in amino acids and high in ammoniacal nitrogen (39.96 and $114 \mu \mathrm{g} / \mathrm{ml})$, respectively with a domination of arginine and glycine (24\% for each) (Table 4$)$.

NPK (3.3:1:4) application increased total amino acids $(155.42 \mu \mathrm{g} / \mathrm{ml})$ and decreased $\mathrm{NH}_{4}{ }^{+}$content $(79.8 \mu \mathrm{g} / \mathrm{ml})$. However, a pronounced increase in lysine $(91 \%)$ and a decrease in most other amino acids was recorded. Replacing potassium by magnesium in the usual NPK formula revealed an increase in ammonia $\left(\mathrm{NH}_{4}{ }^{+}\right)$ content and a decrease in amino acids as compared to NPK treatment (Table 4). Calcium in the formula, however caused ammonia $\mathrm{NH}_{4}{ }^{+}$decrease $(3.56 \mathrm{ug} / \mathrm{ml})$, along with amino acids contents $(30.27 \mu \mathrm{g} / \mathrm{ml})$, indicating the positive role of potassium deficiency in decreasing nitrogen uptake. The dominant amino acids were alanine, glycine, serine, aspartic acid for NPMg treatment and lysine, arginine, proline and glutamic acid for NPCa treatment. Arginine, however, showed negative correlation with disease incidence as expressed by count of the pathogen in crown area $(-0.72$, $P=0.055)$, respectively 
Table (3): Enzymes activity in endogenous potato tissues cropped under different fertilization R4egime in different locations 75 days after planting

\begin{tabular}{|c|c|c|c|c|c|c|c|}
\hline & \multicolumn{7}{|c|}{ Enzymes activities (mg/gm fwt/min) } \\
\hline & Area & 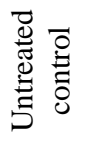 & $\frac{v}{z}$ & $\sum_{\mathrm{Z}}^{\infty 00}$ & $\begin{array}{l}\bigcup^{\pi} \\
\text { Z }\end{array}$ & 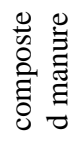 & 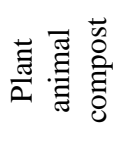 \\
\hline \multirow{4}{*}{$\mathrm{PO}^{1}$} & Manyl-Arus & 2.01 & 1.80 & 1.65 & 1.59 & 1.57 & 1.51 \\
\hline & Ganuob El-Tahrir & 1.26 & 0.83 & 0.99 & 1.02 & 1.10 & 1.64 \\
\hline & Wardan & ND & ND & ND & ND & ND & ND \\
\hline & Talia & ND & ND & ND & $\mathrm{ND}$ & ND & ND \\
\hline \multirow{4}{*}{ CAT } & Manyl-Arus & ND & ND & ND & ND & ND & ND \\
\hline & Ganuob El-Tahrir & ND & ND & ND & ND & ND & ND \\
\hline & Wardan & 0.34 & 0.51 & 0.46 & 0.41 & 0.48 & 0.17 \\
\hline & Talia & 0.54 & 0.51 & 0.49 & 0.51 & 0.41 & 0.38 \\
\hline \multirow{4}{*}{$\mathrm{PPO}^{2}$} & Manyl-Arus & 0.16 & 0.18 & 0.14 & 0.07 & 0.06 & 0.08 \\
\hline & Ganuob El-Tahrir & 0.18 & 0.22 & 0.15 & 0.23 & 0.42 & 0.43 \\
\hline & Wardan & 0.43 & 0.26 & 0.42 & 0.30 & 0.32 & 0.17 \\
\hline & Talia & 0.39 & 0.53 & 0.27 & 0.27 & 0.39 & 0.32 \\
\hline \multirow{4}{*}{$\mathrm{PAL}^{3}$} & Manyl-Arus & 3.89 & 3.88 & 3.89 & 3.05 & 3.88 & 3.90 \\
\hline & Ganuob El-Tahrir & 3.01 & 3.08 & 0.62 & 2.76 & 0.23 & 3.52 \\
\hline & Wardan & ND & ND & ND & ND & ND & ND \\
\hline & Talia & ND & ND & ND & ND & ND & ND \\
\hline \multirow{4}{*}{$\mathrm{TAL}^{4}$} & Manyl-Arus & 0.54 & 0.39 & 0.81 & 0.25 & 1.52 & 0.38 \\
\hline & Ganuob El-Tahrir & 0.34 & 0.33 & 0.09 & 0.37 & 0.22 & 0.32 \\
\hline & Wardan & ND & ND & ND & ND & ND & ND \\
\hline & Talia & ND & $\mathrm{ND}$ & $\mathrm{ND}$ & $\mathrm{ND}$ & $\mathrm{ND}$ & $\mathrm{ND}$ \\
\hline \multirow{4}{*}{$\begin{array}{c}R . \\
\text { solanacearum } \\
\text { 1a. 3a in crown } \\
\text { area } \log _{10} \\
\text { CFU/g) }\end{array}$} & Manyl-Arus & 2.56 & 4.64 & 0.00 & 0.00 & 3.01 & 0.00 \\
\hline & Ganuob El-Tahrir & 4.70 & 6.30 & 4.72 & 3.42 & 4.38 & 3.00 \\
\hline & Wardan & 2.30 & 0.00 & 0.00 & 0.54 & 0.75 & 0.00 \\
\hline & Talia & 3.11 & 2.60 & 0.64 & 2.76 & 2.66 & 1.97 \\
\hline \multirow{4}{*}{$\begin{array}{c}\text { Potato } \\
\text { production } \\
\text { ton/ha }{ }^{\mathrm{lb}, 2 \mathrm{~b}} \text {, } \\
3 \mathrm{~b}, 4 \mathrm{~b}\end{array}$} & Manyl-Arus & 28 & 40 & 33 & 40 & 37 & 34 \\
\hline & Ganuob El-Tahrir & 5 & 6 & 4 & 5 & 6 & 4 \\
\hline & Wardan & 37 & 21 & 24 & 24 & 22 & 22 \\
\hline & Talia & 55 & 59 & 77 & 55 & 101 & 73 \\
\hline
\end{tabular}

1a significant negative correlation with PO $(-0.5, P=0.05)$.

$2 \mathrm{~b}$ significant positive correlation with PPO $(+0.5, P=0.006)$.

3a significant negative correlation with PAL $(-0.52, P=0.04)$.

$3 \mathrm{~b}$ significant positive correlation with PAL $(+0.57, P=0.02)$.

$4 \mathrm{~b}$ significant positive correlation with TAL $(+0.5, P=0.05)$.

Increase in enzyme activity was marked as bold font and decrease in activity was marked as grey highlight

Egypt. J. Phytopathol., Vol. 47, No. 1 (2019) 
Composted chicken manure has influenced the root exudates of potato either qualitatively or quantitatively. Chicken manure increased $\mathrm{NH}_{4}{ }^{+}$content (115.8 $\mu \mathrm{g} / \mathrm{ml})$ and lowered total amino acids content $(22.88 \mu \mathrm{g} / \mathrm{ml})$. However, the plant animal compost (1:1 weight) has generally increased amino acids content and ammonia $(154.6$ and $167.36 \mu \mathrm{g} / \mathrm{ml})$ which indicates better assimilation of $\mathrm{NH}_{4}{ }^{+}$ nitrogen into amino acids (Table 4).

Table (4): Amino acids in root exudates of potato grown under different fertilization regimes in Many-Arus area

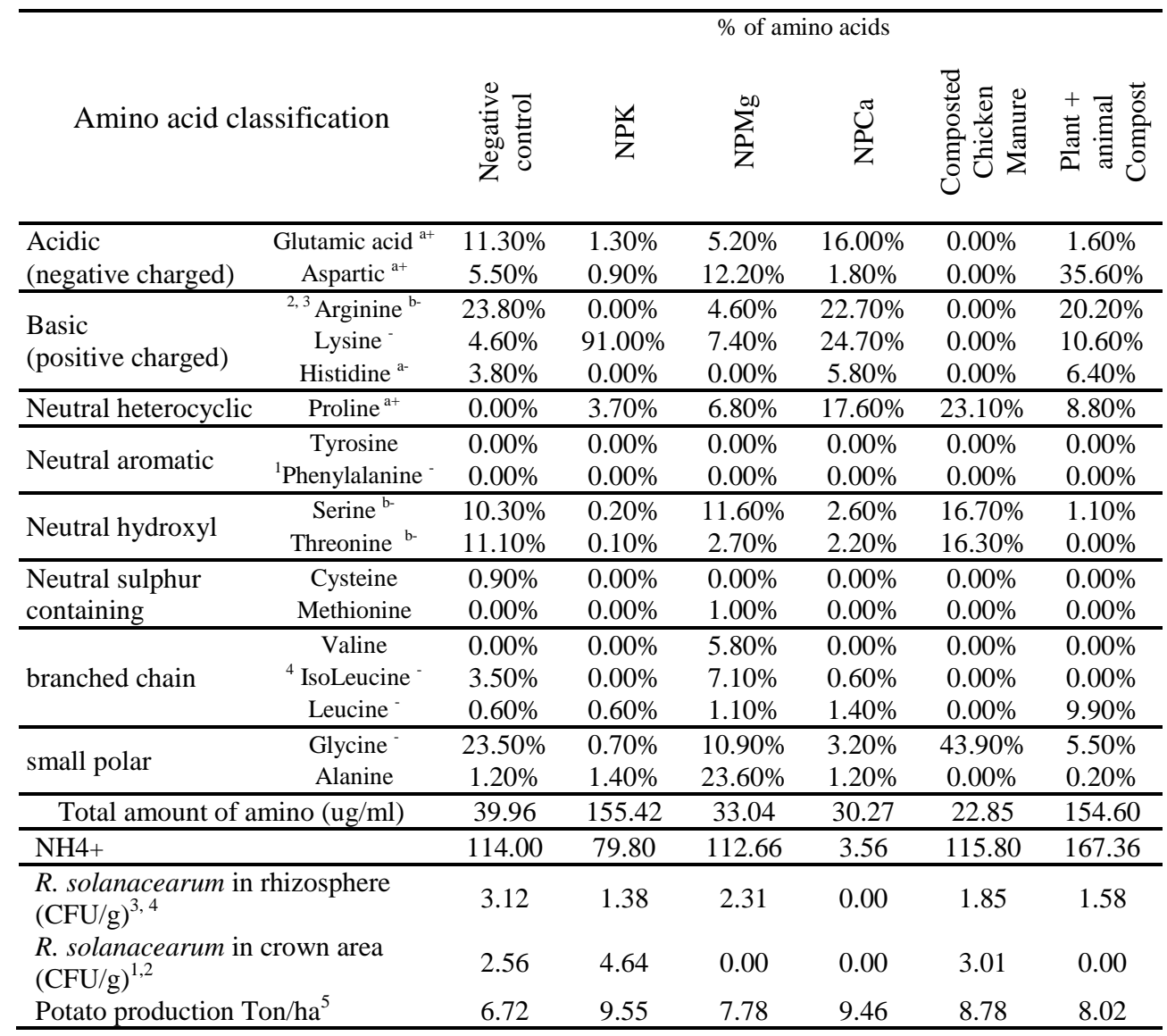

Arginine: Trend of significant correlation $(-0.72, P=0.055)$ with count of the pathogen in crown area Isoleucine: Trend of significant correlation $(+0.68, P=0.07)$ with count of the pathogen in rhizosphere Isoleucine: Significant correlation $(-0.76, P=0.04)$ with potato production 


\section{6- Potato growth stimulation and productive potentials}

As a general trend, significant positive correlation between $\mathrm{N}$ content and count of the pathogen in plant tissues $(+0.58, P=0.02)$ as well as $\mathrm{N}$ content in soil and count of the pathogen in rhizosphere $(+0.69, P=0.007)$ were recorded (Table 2). However, significant negative correlation between phosphorus content in soil and count of the pathogen in rhizosphere $(-0.45, P=0.07)$ was recorded. Trend of significant negative correlation was recorded between $\mathrm{K}$ content in soil and count of the pathogen in rhizosphere $(-0.57, P=0.1)$. Significant negative correlation between soil $\mathrm{pH}$ and count of the pathogen in soil was recorded $(-0.64, P=0.01)$, the relation was reversed for Talia (under lower $\mathrm{pH}$ conditions) $(+0.88, P=0.01)$. Moreover, Significant correlation between soil EC and count of the pathogen in rhizosphere was recorded $(+0.5, P=0.037)$, contrary to area 3 (Talia) (higher EC) $(-0.87$, $P=0.01)$. Moreover, a significant correlation $(-0.57, P=0.1)$ was recorded between soil OM content and count of the pathogen in rhizosphere. However, a significant negative correlation $(-0.5, P=0.05)$ between $\mathrm{C} / \mathrm{N}$ ratio and count of the pathogen in rhizosphere was recorded (Table 2).

\section{7- Crop production and Potato vegetative growth at different treatments}

In general, a positive correlation between crop production and the enzymes PO, PPO, PAL \& TAL activities $(+0.7, P=0.006),(+0.5, P=0.006),(+0.57, P=0.02) \&$ $(+0.5, P=0.05)$, respectively was recorded (Fig $2 \&$ Table 3$)$.

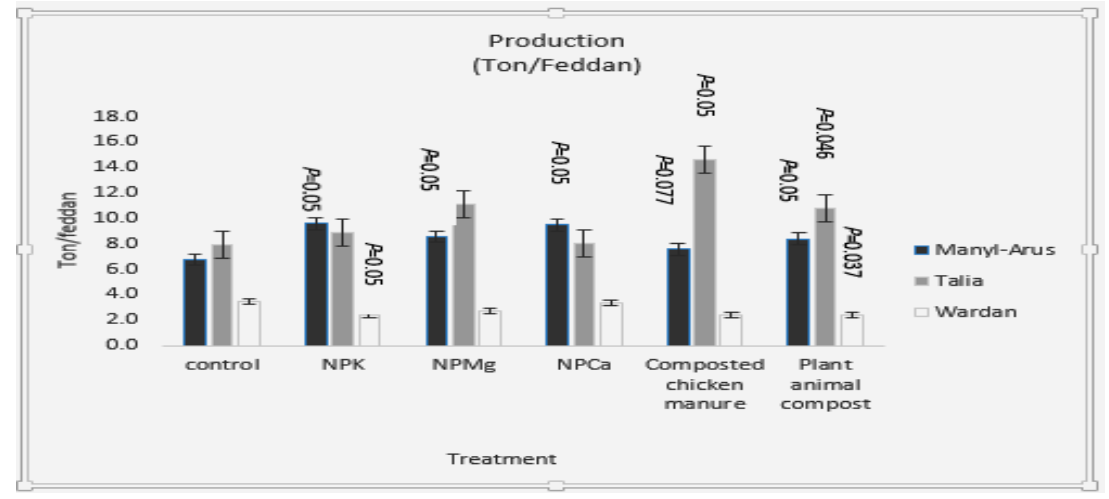

Fig (2): Crop production for different fertilization regimes at different locations. Mann-Whitney U, Asymp. Sig. (2-tailed) was employed to compare parameters of disease incidence for different treatments with untreated control

NPK caused a significant increase in yield production $(19 \%, P=0.05)$ as compared to untreated control at area 1 (Manyl-Arus) that caused a significant Egypt. J. Phytopathol., Vol. 47, No. 1 (2019) 
increase $(P=0.05)$ in vegetative growth (fresh weight, leaf weight ratio and dry weight), but not in yield at 3 (Talia). In contrast, significant decrease in crop yield (29\% decrease) was recorded at area 4 (Wardan) $(P=0.05)$ while a significant increase in leaf weight and ratio was recorded $(P=0.05)$.

NPMg increased yielding significantly $(27 \%, P=0.05)$ at area 1 (Manyl-Arus), and significantly increased leaf wt. ratio, along a significant decrease in dry wt. at area 3 (Talia). NPMg significantly increased vegetative fresh and dry wt. $(P=0.05)$ without significant increase in crop yielding potential.

NPCa formula, increased significantly the crop $(40 \%, P=0.05)$ only at area 1 (Manyl-Arus) and was not effective at the two other areas.

Composted chicken manure caused a significant increase in crop yield (12\%, $P=0.07)$ at area 1 (Manyl-Arus) and $(45 \%, P=0.05)$ at area 3 (Talia) which was associated with significant increase in plant fresh and dry wt. $(P=0.05)$.

Plant animal compost caused a significant increase in crop yield (24\%, $P=0.05)$ at area 1 (Manyl-Arus) and $(13 \%, P=0.046)$ at area 3 (Talia) which was associated with a significant increase in percentage of leaf wt. to total foliage fresh $(P=0.05)$. On the other hand, a significant decrease in crop yield $(28 \%, P=0.037)$ although a significant increase in the fresh and dry foliage were recorded at this area $(P=0.05)$.

It is worth noting that a significant negative correlation was recorded between densities of the pathogen in rhizosphere and potato production $(r=-0.888, P=$ $0.003)$ and trend of negative correlation between wilt severity and potato yielding ( $r$ $=-0.661, P=0.074)$.

\section{Dis c u s s i on}

Disease suppression of potato plants under investigation was correlated with qualitative and quantitative changes in root exudates, enzymes activities, soil characteristics and its NPK content, fertilization regimes.

The lower $\mathrm{C} / \mathrm{N}$ ratio at area 2 (Ganuob El-Tahrir) (sandy soil) accelerated the OM decomposition and hence increased microbial activity as proven earlier by Cong et al., (2015). Negative correlation between soil organic matter content and survival of $R$. solanacearum in soil was discussed by Balabel et al., (2005) and Messiha et al., (2007).

In general, negative correlation was recorded between enzyme activity and disease incidence $(-0.53, P=0.04)$. This negative correlation was clear for untreated treatments, meanwhile, all treatments, however, decreased PO activities. Disease suppression was coincided with a decrease in activities of PO and PPO activities as well as an increase in TAL activity. TAL activity is known to link with disease resistance. Both PAL and TAL thought to be involved in the biosynthesis of resveratrol (phytoalexins) which is involved in plant disease resistance (Jeandet et 
al., 2013). Also, a significant positive correlation was recorded between PAL \& $\mathrm{TAL}$ activities and crop production.

The suppressive effect of NPK treatment was shown related to the soil at area 1 (Manyl-Arus) and was found to be most suppressive at area 4 (Wardan area), with the most alkaline ( $\mathrm{pH}$ 8.8). Messiha et al., (2007) correlated the NPK suppressive effect to ammonium and potassium. The conversion rate of ammonium into ammonia (general microbial toxin) increases by increasing alkalinity (Kissel et al., 1985 \& Messiha et al., 2007). On the other hand, the disease incidence in plant tissues at area 1 (Manyl-Arus) was accompanied by a noticeable increase in lysine which was increased under stress conditions (Galili et al., 2001). Such contradictory findings, between decreased densities of the pathogen in soil and increased severity may be attributed to the noticeable elevation of lysine.

Application of NPK increased crop yield only at area 1 (Manyl-Arus) and increased in foliage growth opposite to decrease in crop yield at area 4 (Wardan). The low nitrogen content at area 4 (Wardan) may be coincided with the possible gas loss from soil (Vos and MacKerron, 2000). Moreover, failure absorbance of P and K from soil may be attributed to high soil alkalinity.

The disease was most suppressed at area 4 (Wardan) which was accompanied by an increase in CAT, and a decrease in PPO activities. This result was opposite reversed at area 3 (Talia) where the disease was not suppressed. PO and CAT enzymes are involved in removal of Reactive Oxygen species (ROS) and hence enhanced plant defense (Sharma et al., 2012).

NPMg treatment suppressed the pathogen to undetected level in most plant tissues. The suppressive effect was most clear at area 4 (Wardan) where the pathogen was undetectable also in soil and potato rhizosphere. Disease retardation was accompanied by a decrease in activities of PO and PPO as well as an increase in TAL activity. However this activity is known to be involved in disease resistance. Moreover, a significant positive correlation was recorded between PAL \& TAL activities and crop yield. Meanwhile, NPMg caused a trend of increase in crop yield and the exception was recorded at area 2 and 4 because of edaphic factors (low $\mathrm{C} / \mathrm{N}$ and $\mathrm{OM} \%$ for area 2) and high $\mathrm{pH}$ which limited nutrient uptake for area 4. Root exudates of NPMg treated plant relatively showed high ammonium and low amino acid contents. Meanwhile, amino acids were more diverse with dominance of alanine. It is well documented that $\mathrm{Mg}$ increases nitrogen uptake, enhances photosynthesis and reactive oxygen species (ROS) (Grzebisz et al., 2010). Moreover, $\mathrm{N}$ and $\mathrm{K}$ deficiencies thought to cause a decrease in total amino acid in root exudates (Carvalhais, 2011). At area 3 (Talia), NPMg treatment decreased C/ N ratio that may be attributed to a decrease in soil OM and an increase in soil and plant $\mathrm{K}$ contents. The decrease in $\mathrm{OM}$ usually associated with increase in soil bacterial 
activity as documented by Shunfeng et al., (2013) that may have enhanced K uptake by the plant.

NPCa treatment caused limited disease suppression which was limited to the plant tissues at area 1 (Manyl-Arus) and was not effective at the other areas. Calcium plays an important role in the resistance of plants against bacterial pathogens (Bateman and Miller, 1966; Berry et al., 1988), by improving the integrity of plant cell wall. Relative low ammonium and amino acid contents were recorded which indicates low $\mathrm{N}$ uptake. Furthermore, $\mathrm{K}$ deficiency thought to decrease in $\mathrm{N}$ uptake as explained by Carvalhais, (2011).

Composted chicken manure showed a clear suppressive effect only in soil at area 1 (Manyl-Arus), but in rhizosphere and plant tissue at area 4 (Wardan). The disease suppression in area 1 (Manyl-Arus) was associated with decreased PO, PPO and increased in TAL (similar to NPMg treatment). Relatively high ammonium and low amount of different amino acids were recorded in potato root exudates. The dominant amino acids were glycine, followed by proline, serine and threonine (neutral amino). Serine and threonine attract some species of fluorescent pseudomonas (Nikata et al., 1993) which may explain the high ratio of fluorescent pseudomonas recovered from soil treated with composted cow manure (Messiha $e t$ al., unpublished), and may explain the undetected pathogen in soil. Composted chicken manure caused general increase in $\mathrm{C} / \mathrm{N}$ ratio which is expected to minimize the OM decomposition by reducing the soil microbial activity (Shunfeng et al., 2013). Soils with high $\mathrm{C} / \mathrm{N}$ ratio are less conducive to soil diseases (Grunwald, 1997). The treatment increased $\mathrm{N}$ uptake by plant which was translated into an increase in crop yield at area 3 (Talia).

Plant-animal compost showed a suppressive effect in area 1 (Manyl-Arus) and in area 4 (Wardan) and was not effective in Talia area. This treatment showed general increase in both amino acid and $\mathrm{NH}_{4}^{+}$as compared to negative control. High ratio of each of aspartic (acidic) and arginine (basic) was recorded. A positive correlation was recorded between arginine and disease incidence. Aspartic acid enhanced growth and pathogenic potential of the pathogen (Yao and Allen, 2006) which may reflect the limited effect of the treatment at some cases. Plant-animal compost showed a great decrease in soil organic matter which was associated with a narrow $\mathrm{C} / \mathrm{N}$ ratio and limited $\mathrm{N}$ and $\mathrm{K}$ plant uptake at area 3 (Talia). The decomposition of $\mathrm{OM}$ at area 3 (Talia) may enhance the microbial diversity which accelerates the $\mathrm{OM}$ decomposition. On the other hand, the same treatment caused an increase in $\mathrm{N}$ and $\mathrm{K}$ plant uptake in area 4 (Wardan). Intermediate OM decomposition may be considered a soil health indicator (van Bruggen, \& Semenov, 2000). Moreover, Negative correlation between survival of $R$. solanacearum and organic matter content was recorded by Balabel et al., (2005) and Messiha et al., (2007). These results may show the suppressive effect of plant-animal compost at area 4 (Wardan) and not in area 3 (Talia). 
This study aimed to address soil and plant health indicators for potato crop following different mineral and organic fertilization regimes in different soil types located at different geographical locations. The contradictory effect of different fertilization regimes at different areas was correlated with difference interrelated edaphic factors

\section{Acknow led gments}

This project was funded by the STDF 2905, Egyptian Ministry for Scientific Research entitled "Environmental friendly program for controlling potato brown rot in Egypt". The authors appreciate the support of Prof. Abou Serie M. Ismail (former head of the Potato Brown Rot Project (PBRP)) for supporting the work.

\section{References}

Aebi, H. 1984. Catalase in vitro. Methods Enzymology, 105: 121- 126.

Anonymous, 1998. Council Directive 98/57/EC of 20 July 1998 on the control of Ralstonia solanacearum (Smith) Yabuuchi et al. Publication 97/647/EC, Official Journal European Communities, L235: 8-39.

Balabel, N.M.; Ewed, W.E.; Mostapha, M.I. and Farag, N.S. 2005. Some epidemiological aspects of Ralstonia solanacearum. Egyptian Journal of Agricultural Research, 83: 1547-1563

Bateman, D.F. and Miller, R.L. 1966. Pectic enzymes in tissue degradation. Annual Reviews of Phytopathology, 4: 119-44.

Benjamin, N.D. and Montgomery, M.W. 1973. Polyphenoloxidase of royal Ann cherries: Purification and characterization. Journal of Food Science, 38: 799806.

Berner, M.; Krug, D.; Bihlmaier, C.; Vente, A.; Müller, R. and Bechthold, A. 2006. Genes and enzymes involved in caffeic acid biosynthesis in Actinomycete Saccharothrix espanaensis. Journal of Bacteriology, 188: 2666-2673.

Berry, S.; Madumadu, G.; Uddin, M. 1988. Effect of calcium and nitrogen nutrition on bacterial canker disease of tomato. Plant and Soil, 112: 113- 20.

Boubakri, H.; Poutaraud, A.; Wahab, M.A.; Clayeux, C.; Baltenweck-Guyot, R.; Steyer, D.; Marcic, C.; Mliki, A. and Soustre-Gacougnolle, I. 2013. Thiamine modulates metabolism of the phenylpropanoid pathway leading to enhanced resistance to Plasmopara viticola in grapevine. BMC Plant Biology, 13: 31.

Carvalhais, L.C. Dennis, P.G.; Fedoseyenko, D.; Hajirezaei, M-R., Borriss, R.and von Wirén, N. 2011. Root exudation of sugars, amino acids, and organic acids by maize as affected by nitrogen, phosphorus, potassium, and iron deficiency. Journal of Plant Nutrition and Soil Science, 174: 3-11.

Egypt. J. Phytopathol., Vol. 47, No. 1 (2019) 
Cong, W.F.; Hoffland, E.; Li, L.; Janssen, B.H. and Van-der Werf, W. 2015. Intercropping affects the rate of decomposition of soil organic matter and root litter. Plant Soil, 391: 399-411.

Elhalag, K.M.; Emara, H.M.; Messiha, N.A.S.; Elhadad, S.A. and Abdallah, S.A. 2015. The relation of different crop roots exudates to the survival and suppressive effect of Stenotrophomonas maltophilia (PD4560), biocontrol agent of bacterial wilt of potato. Journal of Phytopathology, 163 (10): 829-840.

Elphinstone, W.J.G. 2005. The current bacterial wilt situation: A global overview. In: Allen, C.; Prior, P. and Hayward, A. C. (eds.). Bacterial Wilt: The Disease and the Ralstonia solanacearum Species Complex. American Phytopathological Society, St. Paul, MN, pp. 9-28.

Farag, S.M.A.; Elhalag, K.M.A.; Hagag, M.H.; Khairy, A.M.; Ibrahim, H.M.; Saker, M.T. and Messiha, N.A.S. 2017. Potato bacterial wilt suppression and plant health improvement after application of different antioxidants. Journal of Phytopathology, 165: 522-537.

Galili, G.; Tang, G.; Zhu, X. and Gakiere, B. 2001. Lysine catabolism: a stress and development super-regulated metabolic pathway. Current Opinion in Plant Biology, 4(3): 261-266.

Graham, J.H.; Leonard, R.T. and Menge, J.A. 1981. Membrane mediated decrease in root exudation responsible for phosphorus inhibition of vesicular-arbuscular mycorrhiza formation. Plant Physiology, 68: 548-552.

Grunwald, N.J. 1997. Characterization of Soil Nutrient and Microbial Variables Associated with $P$. aphanidermatum and $R$. solani growth and Tomato Dampingoff during Short-term Cover Crop Decomposition. PhD Thesis, University of California at Davis, 190 pp.

Grzebisz, W.; Przygocka-Cyna, K.; Szczepaniak, W.; Diatta, J. and Potarzycki J. 2010. Magnesium as a nutritional tool of nitrogen management-Plant production and environment. Journal of Elementology, 15: 771-788.

Hagag, M.H.; Elmenisy, A.Z.A.; Fawzi, F.G. and Abd El-Ghafar, N.Y. 2015. Chemical and Organic Amendments for Controlling Potato Bacterial Wilt. Egypt. J. of Phytopathol., 43(1): 41-52.

Janse, J.D. 1988. A detection method for Pseudomonas solanacearum in symptomless potato tubers and some data on its sensitivity and specificity. Bulletin OEPP/EPPO Bulletin, 18: 343-351.

Jeandet, P.; Delaunois, B.; Conreux, A.; Donnez, D.; Nuzzo, V.; Cordelier, S.; Clément, C. and Courot, E. 2010. Biosynthesis, metabolism, molecular 
engineering and biological functions of stilbene phytoalexins in plants. BioFactors, 36: 331-341.

Katsuwon, J. and Anderson, A.J. 1990. Catalase and superoxide dismutase of rootcolonizing saprophytic Fluorescent pseudomonads. Applied and Environmental Microbiology, 56(11): 3576-3582.

Kissel D.E.; Sander D.H. and Ellis R. 1985. Fertilizer-plant interaction in alkaline soils. In: Engelstad, O.P. (Ed.), Fertilizer Technology and Use. Soil Science Society of America, Madison, WI, pp. 153-196.

Lecourieux, D.; Ranjeva, R. and Pugin, A. 2006. Calcium in plant defencesignalling pathways. New Phytologist, 171: 249-269.

Messiha, N.A.S.; van Bruggen, A.H.C.; van Diepeningen, A.D.; de Vos, O.J.; Termorshuizen, A.J.; Tjou-Tam-Sin, N.N.A. and Janse J.D. 2007. Potato brown rot incidence and severity under different management and amendment regimes in different soil types. European Journal of Plant Pathology, 119: 367-381.

Messiha, N.A.S.; van Diepeningen, A.D.; Janse, J.D.; Termorshuizen, A.J.; Schoeman-Weerdesteijn, M.E.; Franz, E. and van Bruggen, A.H.C. 2009. Survival of Ralstonia solanacearum is affected more by soil type than by management. Applied Soil Ecology, 43: 206-215.

Moe, L.A. 2013. Amino acids in the rhizosphere: from plants to microbes. American Journal of Botany, 100(9): 1692-1705.

Nikata, T.; Sumida, K.; Kato, J. and Ohtake, H. 1992. Rapid method for analyzing bacterial behavioral responses to chemical stimuli. Applied Environmental Microbiology, 58: 2250-2254.

Ryan, P.R.; Delhaize, E. 2001. Function and mechanism of organic anion exudation from plant roots. Annual Review of Plant Physiology Molecular Biology, 52: 527-560.

Sharma, P.; Jha, A.B.; Dubey, R.S. and Pessarakli, M. 2012. Reactive oxygen species, oxidative damage, and antioxidative defense mechanism in plants under stressful conditions. Journal of Botany, vol. 2012, Article ID 217037, 26 pages.

Shunfeng, G.; Haigang, X.; Mengmeng, J. and Yuanmao, J. 2013. Characteristics of soil organic carbon, total nitrogen, and $\mathrm{C} / \mathrm{N}$ ratio in Chinese apple orchards. Open Journal of Soil Science, 3: 213-217.

Taranto, F.; Pasqualone, A; Mangini, G; Tripodi, P; Miazzi, M.M., Pavan, S and Montemurro, C. 2017. Polyphenol Oxidases in Crops: Biochemical, Physiological and Genetic Aspects. International Journal of Molecular Sciences 18(2): 377 .

Egypt. J. Phytopathol., Vol. 47, No. 1 (2019) 
Thanh, D.T.; Tarn, L.T.T.; Hanh, N.T.; Tuyen, N.H.; Bharathkumar, S.; Lee, S.V. and Park, K.S. 2009. Biological control of soil borne diseases on tomato, potato and black pepper by selected PGPR in the greenhouse and field in Vietnam. Plant Pathology Journal, 25: 263-269.

Thomson, B.D.; Robson, A.D. and Abbott, L.K. 1986. Effects of phosphorus on the formation of mycorrhizas by Gigaspora calospora and Glomus easciculatum in relation to root carbohydrates. New Phytology, 103: 751-765.

Van-Bruggen, A.H.C. and Semenov, A.M. 2000. In search of biological indicators for soil health and disease suppression. Applied Soil Ecology, 15: 13-24.

Vos, J. and MacKerron, D.K.L. 2000. Basic concepts of the management of supply of nitrogen and water in potato production. In: Haverkort, A.J. and Mackerron, D.K.L. editors. Management of nitrogen and water in potato production, Wageningen, The Netherlands, pp 15-33.

Wang, J. and Lin, C. 2005. Integrated Management in tomato bacterial wilt: The world vegetable center brochure AVRDC. p. 1-14.

Weller, S.A.; Elphinstone, J.G.; Smith, N.C.; Boonham, N. and Stead, D.E. 2000. Detection of Ralstonia solanacearum strains with a quantitative, multiplex, realtime, fluorogenic PCR (TaqMan) assay. Appl. Environ Microbiol, 66(7): 28532858.

Yan, J. 1993. Influence of plant growth regulators on turf grass polar lipid composition, tolerance to drought and saline stresses and nutrient efficiency. Ph.D. Thesis, CSES, Virginia Tech.

Yao, J. and Allen, C. 2006. Chemotaxis is required for virulence and competitive fitness of the bacterial wilt pathogen Ralstonia solanacearum. Journal of Bacteriology, 188: 3697-3708.

Zhao, Y.; Tu, K.; Shao, X.; Jing, W. and Su, Z. 2008. Effects of the yeast Pichia guilliermondii against Rhizopus nigricans on tomato fruit. Postharvest Biology and Technology, 49: 113-120.

Corresponding author: Messiha, N.A.S.

E-mail: nevein_messiha@yahoo.com

(Received 09/03/2019;

in revised form 30/03/2019) 


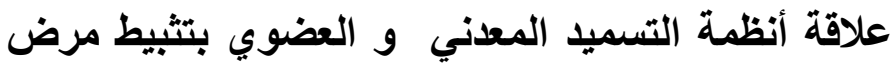 العفن البني في البطاطس و زيادة الأنتاجيه}

د. نيفين أنور شحاته مسيحه ،و د. كامل محمد عطا الحلاج

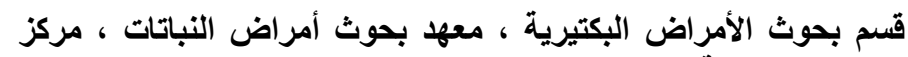

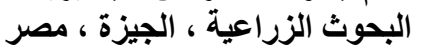

تم تقييم تأثير أنظمة التسميد المختلفة على الذبول البكتيري المتسبب عن أربات

Ralstonia solanacearum

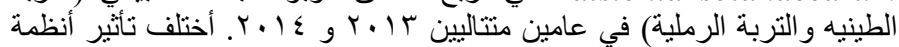

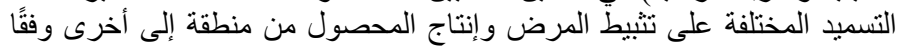
للاختلاف في العوامل الارضيه. المنطقه النيل (منيل العروس، المنوفية) (تربة طينية)

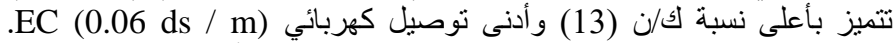

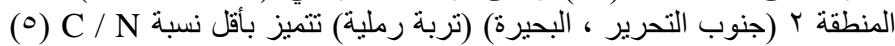

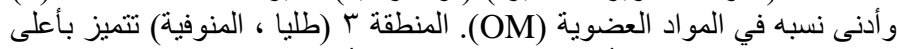

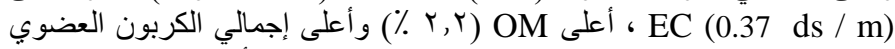

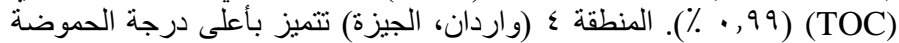

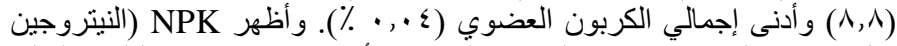

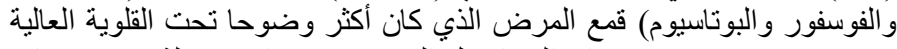

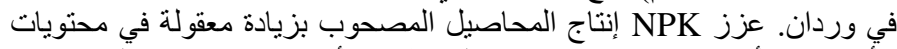

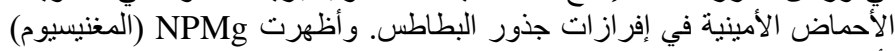

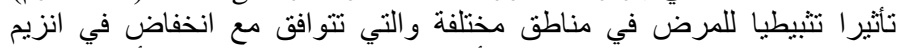

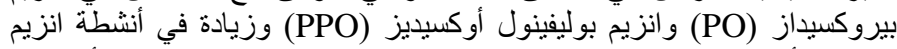

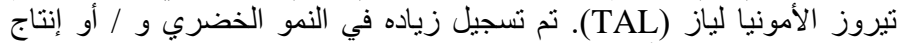

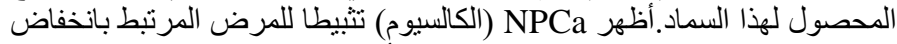

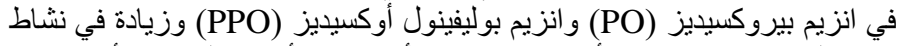

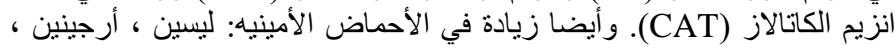

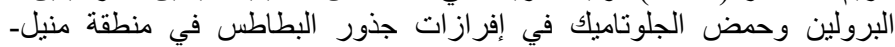

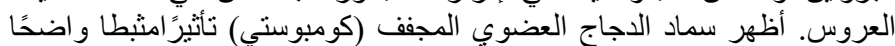

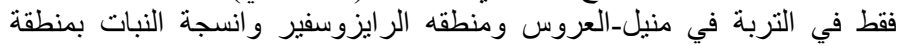

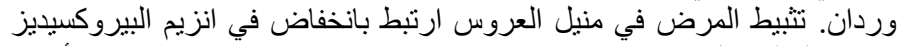

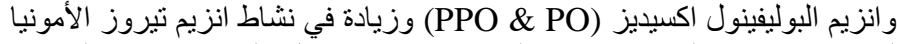

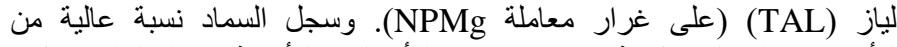

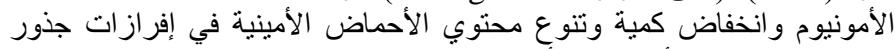

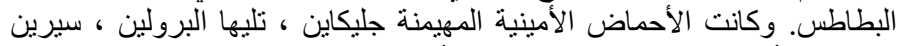

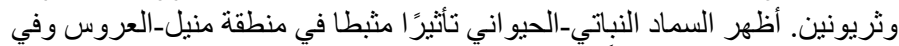

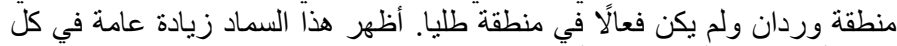

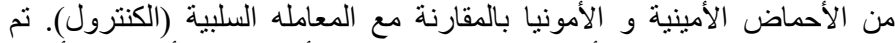

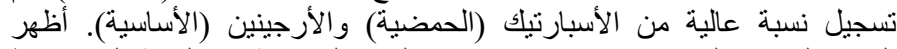

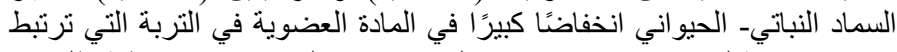

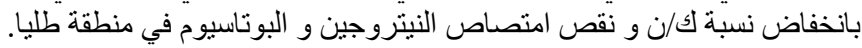

Egypt. J. Phytopathol., Vol. 47, No. 1 (2019) 